\title{
Introduction: German neo-liberalism and its relevance for Austrian economics
}

\author{
Michael Wohlgemuth
}

Published online: 24 March 2013

(C) Springer Science+Business Media New York 2013

Why should (mostly American) readers of the Review of Austrian Economics take the pain and look at the following three papers dealing with German Neo-Liberalism? The short answer is: because they are likely to be "Austrians". I take it that Austrian economists (like myself) show an interest in the history of economic ideas, in matters of methodology, and in big questions of politics and the institutional foundations of the social order that is hardly to be found in the realm of "pure" and "mainstream" economics.

The following papers address these issues and present authors and views that are likely to be rather unfamiliar to most non-German- "Austrian" readers. But there are several good reasons why it might be useful for Austrian economists to look into German neo-liberalism. One is that the authors presented here (Walter Eucken, Wilhelm Röpke, Alexander Rüstow, Alfred Müller-Armack and others) were exposed to the same intellectual climate at roughly the same time as was the second generation of "Austrians": Ludwig von Mises or Friedrich von Hayek. All of them - in the case of the Germans: sooner or later, and more or less-took a brave stand against the tide of totalitarianism and advocated "liberalism"; and all of them searched for a sound methodological basis (mainly in opposition to the German "mainstream" of the Historical School) of their economic research. But all of them did so in very different ways.

One main reason for presenting the founders of German "neo-liberalism" here is to challenge the reader familiar to the works of Austrian Economics to find similarities and differences between these Germans and his/her Austrians. After all, they all shared the same (or: very similar) first language, education, historical experience and culture; they read each others' works and most of them met at important occasions (such as the Colloque Lippman in Paris 1938 and the Mont Pèlerin Society meetings since 1947). For the Misesian reader it will become clear after reading the following papers why Mises, at those occasions, reportedly

\footnotetext{
M. Wohlgemuth $(\bowtie)$

University Witten/Herdecke, Witten, North Rhine-Westphalia, Germany

e-mail: michael@openeuropeberlin.de
} 
called the German neo-liberals no-liberals or even a "bunch of socialists"whereas Hayek, differences of opinion notwithstanding, kept a close friendship with his German colleagues Eucken or Röpke.

Matters of history, ideology and methodology are so dear to Austrian economists (and also to German neo-liberals) that we are both too often inclined to fight each other on details rather than defending our shrinking niche against the overwhelming economics mainstream. I expect that not many of our readers have taken notice of the latest "Methodenstreit" that was raging in German media and economics faculties during the last years (whereas the first Methodenstreit between Menger and Schmoller marks the founding moment or myth of Austrian Economics). A very short account of the latest debate is this: years before the financial crisis broke out, German economics faculties began to get rid of "neo-liberal" chairs in economics that were teaching and doing research in areas of economic policy and "Ordnungspolitik". Their aim was to follow the "leading" American mainstream by doing "pure" research and thereby demonstrate more impact in the wellknown, path-dependent rankings of publications and citations. The case that prompted the latest "Methodenstreit" was Cologne University (and other universities as well) whose economics faculty decided to scrap ** all chairs of economic policy (since Müller-Armack's time a stronghold of neo-liberalism and serious research into economic policy and institutional economics) and establish a cluster of "state of the art" neoclassical macroeconomics instead. In 2009, at the height of the (first stage of) the crisis, some German economists (supported by some part of the German media) protested against this development. The ensuing debate was mostly about methodology (such as the use of mathematics in l'art pour l'art "pure" modeling under bizarre assumptions) and the trade-off between rigor and relevance.

The present three authors (together with Gerhard Wegner ${ }^{2}$ ) argued in a longer newspaper article that "Ordnungsökonomik" (the economics of the social order) is neither a thing of the past nor a German "Sonderweg" (special path of development). Our argument was that much of "Ordnungsökonomik" has preceded research that is now being done internationally under titles such as "New Institutional Economics", "Constitutional Economics" and also "Austrian Economics". The German tradition of treating economics as a broader contribution to the social sciences (and not a narrow application of optimizing mathematics), we argued, deserves to be continued and constantly developed if it is not to be delegated to other social sciences that too often lack an understanding of economics, catallactics and the spontaneous order. To analyze the economic order as being embedded in institutions (both formal and informal) and thus look at the interrelations of social orders in the economy, in politics, law and culture does have a long tradition in Germany. Not all of this tradition has been very fruitful—as some episodes within the German Historical School have shown. But the general research program of a "contextual economics" seems to us more needed and more promising than ever.

\footnotetext{
${ }^{1}$ This is another German concept that cannot easily be translated into English (like: "Schadenfreude", "Leitmotiv", "Blitzkrieg", "Heimat" or others). It means essentially what Hayek (in a very Kantian way) described as the primacy of universalisable rules of just conduct; or in Constitutional Economics is related to the choice of rules rather the use of discretion in manipulating results for specific interests and purposes. ${ }^{2}$ In: Frankfurter Allgemeine Zeitung, June 21, 2009: "Was kann und was ist Ordnungsoekonomik"?
} 
The following papers might substantiate this claim. They present contributions (several times updated) to the conference of the History of Economic Science (HES) conference in Fairfax (VA), 2007. Therefore, the perspective is mostly one of the history of ideas. An economic science that forgets its own history is a poor science; and we believe that a closer look at the debates and struggles that formed some of the most interesting economists before us can also provide some insights and perhaps even ammunition for the debates and struggles that we have before us.

Our special section starts with Joachim Zweynert's paper "How German is German Neo-Liberalism?". He provides insights into the works of Eucken, Röpke, Rüstow, and Müller-Armack by comparing their responses to the British tradition of classical liberalism (Adam Smith) and the German tradition of the Historical School (Gustav Schmoller). Both of these traditions, Joachim argues, provide different backgrounds for understanding German neo-liberals' economics and their theories of the social order-which, in turn, reflect the different historical development of the economy and the social order in the UK and Germany. Still, the reactions of these German "neo-liberals" are quite different, from a rather strict adherence to the Historical School (Müller-Armack) to a rather Smithian approach (Eucken) and a combination of sober economics with conservative romanticism and cultural pessimism concerning social cohesion (Röpke and Rüstow). This paper already makes clear that we are not trying to praise German neo-liberalism and "sell" it to (American) "neo-Austrians". We want to raise some curiosity towards most interesting and most controversial ideas (still relevant today) that have at least this to claim in their favor: they combined economic with sociological, historical, philosophical (and often even theological) reflections in a way that mainstream economics has long lost the ability to do.

The second paper of Nils Goldschmidt explores these combinations with regard to the eminent founder of the "Freiburg School", Walter Eucken. This is a paper that should interest the Austrian economist fascinated by methodological matters. Max Weber's concept of "ideal types" and Edmund Husserl's "phenomenology" had an important influence not only on Mises or Hayek but also on several presentgeneration "neo-Austrians". How did Eucken integrate these ideas (of colleagues whom he knew personally and who also taught in Freiburg) into his own methodology of economics and what influence did they have on his ideal of an equally workable and humane social order? Nils brings a third man into the picture: Eucken's father, a Nobel-Price winning philosopher and at his time leading protagonist of German neo-idealism. This fascinating amalgam of influences is needed to explain why Eucken was able to uphold principles such as order, freedom and truthfulness against his Freiburg "colleague" Martin Heidegger and the Nazi regime and why his contributions (prepared in secretive ** opposition) to the post-war German "Social Market Economy" became that important.

Finally, my own paper "The Freiburg School and the Hayekian Challenge" investigates more directly into the relation between the German "neo-liberals" and Austrian economics. Freiburg University is very proud of "its" Nobel Price laureate, and there is a strong endeavor to link Hayek to the Freiburg School of German neoliberalism. There are (beyond sheer marketing) some good reasons for that link. However, in my paper I prefer to stress some important differences between Austrian (Hayekian) economics and the (older) Freiburg School. My point is that in terms of 
the emergence or imposition of rules, the "social question" and the theory/role of competition, Hayek and "Freiburg" differ substantially. And, I argue, these differences can be explained to a large degree by the different focus of the two distinct but related leading questions: the accumulation of private power (Freiburg) and the distribution of private knowledge (Hayek).

Alright, you may find, you Germans definitively love to complicate things and plague us readers with concepts such as "universalizabilty" (Kant/Hayek), or even untranslatable concepts such as "Ordnungspolitik", "Sonderweg", "Gemeinschaft", "Gesellschaft", "Vermassung" and the like. But at least Austrian economists still care about such complexities, I hope. The ideas presented here have the same roots as those of Austrian economics. To be sure: German neoliberals have grown to become somewhat different plants. But they, and their remaining off-springs, are joint with (neo-) Austrians on the list of a very similar endangered species. 